Vol. 24, No. 2, April 2021, hlm. 207-216

p-ISSN: 1410-9344; e-ISSN: 2549-5631

WARTA LPM

homepage: http://journals.ums.ac.id/index.php/warta

\title{
Pemberantasan Buta Aksara dan Bekal Hidup Mandiri Masyarakat Onggaya Distrik Naukenjerai Kabupaten Merauke Papua
}

\author{
${ }^{1}$ Adi Sumarsono, ${ }^{2}$ Yus Witdarko, ${ }^{3}$ Dina Fitri Septarini \\ ${ }^{1}$ Jurusan Pendidikan Jasmani Kesehatan dan Rekreasi, Universitas Musamus \\ ${ }^{2} J u r u s a n$ Teknik Pertanian, Universitas Musamus \\ ${ }^{3}$ Jurusan Akuntansi, Universitas Musamus \\ Email: adi@unmus.ac.id
}

\section{Article Info}

Submitted: 24 September 2020

Revised: 23 November 2020

Accepted: 9 December 2020

Published: 21 April 2021

Keywords: Iliterate and independent life
Kata kunci: buta aksara, hidup mandiri

\section{Abstract}

This KKN-PPM service aims to provide direct knowledge to the community as the implementation of knowledge from the academic environment. Two things that are the goals of this program are the eradication of illiteracy and the provision of independent living for the people in Onggaya Village, Neukenjerai District, Merauke Regency, Papua Province. The method used in this program includes community empowerment in the form of Real Work Lectures (KKN) through training, implementation and mentoring.The implementation of this Community Service Program was carried out in August 2020, which of course coincides with the already universal COVID-19 pandemic. This $K K N$ / PPM activity is carried out in compliance with the health protocol rules that are required by the government. The result of this KKN-PPM activity is the application of knowledge in accordance with the methods and objectives to the community. Quantitatively, the focus of education in teaching basic Calistung has met the target, the achievements of the participating subjects have increased, the knowledge and understanding of the subjects have also increased by $19.69 \%$. This is because it is more on the way and style of learning that is contextual in accordance with the characteristics of the state of society. The focus of the agricultural sector has increased in recognizing the variety of natural fertilizers, a more flexible planting method with the characteristics of local farmers' land conditions. The results of the provision of living independently in agricultural farming also reached 20\%, this is due to the support of the community who are enthusiastic in using their land, as well as the motivation of the community to produce crops with good results during the COVID-19 pandemic.
Pengabdian KKN-PPM ini bertujuan untuk memberikan bekal ilmu langsung kepada masyarakat sebagai implementasi ilmu dari 
lingkungan akademik. Dua hal yang menjadi tujuan dari program ini adalah pemberantasan buta aksara dan bekal hidup mandiri kepada masyarakat yang ada di Kampung Onggaya, Distrik Neukenjerai yang berada di Kabupaten Merauke, Provinsi Papua. Metode yang digunakan dalam program ini meliputi pemberdayaan masyarakat dalam bentuk Kuliah Kerja Nyata (KKN) melalui cara pelatihan, penerapan dan pendampingan. Pelaksanaan KKN ini dilaksanakan pada bulan Agustus 2020, yang tentunya bersamaan dengan masa pandemi Virus COVID-19 yang sudah universal. Kegiatan KKN/PPM ini dilaksanakan dengan mematuhi aturan protokol kesehatan yang sudah diwajibkan oleh pemerintah. Hasil kegiatan dari KKN-PPM ini adalah diterapkannya ilmu sesuai dengan metode dan sasaran ke masyarakat. Secara kuantitatif fokus pendidikan dalam mengajarkan dasar calistung sudah sesuai dengan target, capaian dari subyek yang sudah berpartisipasi meningkat, pengetahuan serta pemahaman subyek juga mengalami peningkatan 19,69\%. Hal ini dikarenakan lebih pada cara dan gaya pembelajaran yang konstektual sesuai dengan karakteristik keadaan masyarakat. Fokus dari bidang pertanian sudah mengalami peningkatan dalam mengenal ragam membuat pupuk secara alami, cara tanam yang lebih fleksibel dengan keadaan karakteristik lahan petani setempat. Hasil dari kegiatan bekal hidup mandiri dalam bercocok tanam bidang pertanian juga mencapai $20 \%$, hal ini karena dukungan masyarakat yang semangat dalam menggunakan lahan miliknya, serta motivasi masyarakat untuk menghasilkan hasil tanaman dengan hasil yang lumayan saat pandemi COVID-19.

\section{PENDAHULUAN}

Program pembangunan insfrastruktur yang dilakukan oleh Presiden Joko Widodo pada pemerintahan periode pertama terbentang luas dari Pulau Jawa sampai di Papua. Salah satu program yang mengutamakan daerah 3T (terluar, tertinggal, dan terpencil) dalam prioritas pembangunan dapat dirasakan oleh masyarakat Indonesia. Sedangkan pada periode yang kedua, program yang hendak di laksanakan adalah pembangunan Sumber Daya Manusia, sudah dimulai dengan program pro rakyatnya. Pada intinya tujuan dari pembangunan yang menggunakan media apapun pada hakikatnya adalah pembangunan untuk manusia. Pembangunan yang baik adalah pembangunan yang tidak hanya berfokus pada pertumbuhan ekonomi semata, tapi juga berfokus pada pembangunan manusia. Karena manusia adalah tujuan akhir pembangunan sudah seharusnya memiliki pilihan yang luas dalam hidup untuk mencapai tingkat kualitas hidup yang lebih baik.
Provinsi Papua yang berada di ujung timur Indonesia mempunyai kekayaan alam yang sangat beragam. Hasil alam yang melimpah tersebar dari ujung Papua Barat hingga perbatasan dengan Negara tetangga Papua New Guinie (PNG). Pemanfaatan hasil alam yang kaya pada kenyataannya masih menyisakan permasalahan yang sangat dasar dari kehidupan manusia. Hal ini dapat dilihat dari dasar permasalahan bidang pendidikan dan kesehatan yang hingga kini masih belum selesai disetarakan dengan kawasan Indonesia Barat. Tingkat dari kesejahteraan hidup di Papua dapat dilihat dari angka Indeks Pembangunan Manusia. Indeks Pembangunan Manusia pada tahun 2011 berdasarkan data Badan Pusat Statistik 2011, provinsi Papua merupakan daerah dengan Indeks Pembangunan Manusia (IPM) terendah dari 33 Provinsi di Indonesia. Nilai IPM Provinsi Papua sebesar 65,36 persen dan yang tertinggi adalah DKI Jakarta 77,97 persen (Kartono, 2013).

Mitra yang dilibatkan dalam kegiatan KKN/PPM ini adalah masyarakat lokal Papua 
yang berada di Kampung Onggaya Distrik Naukenjerai Kabupaten Merauke Papua. Permasalahan pendidikan yang ada di Kampung ini adalah masih ditemuinya keterbatasan dari masyarakat dalam mengenal aksara baik secara lisan maupun verbal. Keterbatasan dalam bidang pendidikan ini sangat dapat dirasakan tak kala musim pandemi yang mengharuskan siswa usia sekolah untuk belajar dirumah. Keterbatasan insfrastruktur pendidikan yang juga memberikan faktor kendala berjalannya proses pendidikan di daerah ini. selain itu permasalahan yang kedua yaitu keberadaan Kampung Onggaya berada di pinggir pesisir pantai, keberadaan dari kampung ini mempunyai ciri khas yaitu penduduk yang sudah mulai bermata pencaharian sebagai nelayan dan bertani. Keberadaan tanah di pesisir pantai sebelah dari hunian warga sangat cocok untuk dilakukan bidang pertanian. Hasil dari pertanian di wilayah Kampung Onggaya sudah dapat dirasakan untuk kebutuhan seharihari. Diantara dari hasil pertanian di Kampung Onggaya adalah padi, cabai, dan bermacam sayuran. Pengolahan lahan yang dilakukan secara tradisional terkadang tidak sebanding dengan hasil yang diharapkan, hal ini dapat dicermati bahwa secara bertahap hasil dari tanaman mengalami penurunan. Berdasarkan dari hasil observasi dan pendalaman informasi kepada warga masyarakat diketahui bahwa masih banyak masyarakat dalam bercocok tanam belum menguasai jenis cara pemupukan, cara memaksimalkan pembuatan pupuk alami serta masih terkendalanya dalam mengatasi pengobatan pestisida dari hama dan penyakit pada tanaman.

Berdasarkan dari uraian permasalahan yang dialami Mitra pada kegiatan pengabdian ini di fokuskan pada dua bidang yaitu pendidikan dan bidang pertanian. Adapun solusi yang dilaskanakan pada fokus pengabdian ini diberikan solusi secara terukur dan terstruktur yaitu melalui implementasi ilmu terapan yang langsung bersinggungan dengan kebutuhan masyarakat yaitu dilaksanakan oleh mahasiswa melalui kegiatan Kuliah Kerja Nyata (KKN). Solusi yang diberikan pada kegiatan ini melalui pembelajaran dan pemberdayaan masyarakat (PPM) melalui usaha pemberantasan buta aksara melalui program calistung dan peningkatan bekal hidup mandiri masyarakat melalui bidang pertanian.

Pada penerapan ilmu dari bidang pendidikan dengan mengimplementasikan metode evaluasi belajar Imagination Box (Sumarsono \& Mubarokah, 2019). Pada kegiatan implementasi ini siswa dan warga belajar binaan KKN dilakukan evaluasi secara bertahap dalam mendapatkan materi membaca, menulis, dan berhitung secara berkala. Pada kegiatan pembelajaran juga menerapkan kegiatan belajar juga menerapkan media interaktif dalam meningkatkan (Sumarsono \& Sianturi, 2019). Hasil dari penelitian ini mengindikasikan bahwa belajar dengan melibatkan interaksi siswa dalam bentuk media sangat membawa suasana pembelajaran yang lebih aktif dan kreatif. Jika subyek belajar sudah meningkat motivasi maka akan berimbas pada peningkatan kompetensi siswa dalam menyerap pendidikan.

Pada bidang pendidikan yang akan dilaksanakan pada kegiatan pengabdian ini mengacu pada hasil penelitian sebagai solusi dalam meningkatkan mutu belajar. Implementasi dari pembelajaran yang akan digunakan dalam proses pengabdian ini adalah penggunaan media belajar intraktif dan juga media belajar yang berbasis alam yang menyesauaikan dengan keadaan lingkungan siswa (Sumarsono \& Sianturi, 2018). Penyesuaian dari tahapan belajar pada kegiatan pengabdian KKN PPM ini diseusikan dengan keberadaan proses dan karakteristik siswa (Sumarsono, Adi; Santo, Zem; Hidayat, Afif Khoirul, 2017).

\section{Pemberantasan Buta Aksara}

Luasnya wilayah Indonesia jika dinilai secara objektif masih terjadi ketimpangan antara kesejahteraan di Wilayah Indonesia Barat dan Wilayah Indonesia Timur. Hal yang bisa di gambarkan contoh sederhana adalah keberadaan tiga masalah pokok yang masuk dalam prioritas pembangunan Nasional yaitu, pendidikan, kesehatan, dan ekonomi. Salah satu aspek dalam menunjang kemajuan dari suatu bangsa tidak terlepas dari masalah kualitas Sumber Daya Manusia (SDM). Pendidikan yang sudah berjalan selama tujuh puluh lima tahun dapat dirasakan bahwa masih ditemui permasalahan di Papua khususnya di Kabupaten Merauke. Secara bangunan dan sistem yang 
sudah dijalankan memang pendidikan sudah masuk hingga daerah pelosok. Akan tetapi jika dilihat dari hasilnya ternyata belumlah semua merasakan pendidikan hingga selesai. Kampung Onggaya Distrik Neukenjerai sudah banyak masyarakat yang sadar untuk menomorsatukan pendidikan anaknya. Program KKN/PPM ini mempunyai fokus dalam mendukung program pemerintah dalam memberantas buta akasara.

Persoalan pendidikan saat terjadi Virus Pandemi Covid-19 yang melanda seluruh Indonesiaberdampakjuga pada penyelenggaraan pendidikan di daerah-daerah di Papua. Penyelenggaraan pendidikan pada jenis Sekolah Dasar di Kampung Onggaya berjalan sesuai dengan arahan pemerintah yaitu pembelajaran tatap muka terbatas. Penyelenggaran berbasis online masih belum bisa dilakukan karena terbatasnya jaringan internet di sekitar Onggaya. Untuk mempertimbangkan pembelajaran berbasis daring sebenarnya terdapat kelemahan dan kelebihannya. Kelebihan dari pembelajaran jarak jauh terbukanya akses pendidikan yang tidak hanya di efektifkan melalui tempat dan waktu juga dapat melibatkan pakar dari berbagai latar belakang ilmu yang lebih beragam untuk turut andil dalam proses pembelajaran. Selain itu kekurangannya harus mengandalkan teknologi video dan audio yang menyebabkan pengalaman sendiri dalam individu (Setiawan, 2020). Akan tetapi pembelajaran secara daring juga tidak boleh dilakukan secara terus menerus karena faktor yang lain akan menggantikan peran media. Proses belajar mengajar yang dilakukan secara online selayaknya tidak dilaksanakan dalam durasi panjang dan memakan waktu lama, hal ini dikarenakan peserta didik akan mengalami kesulitan dalam mempertahankan konsentrasi lebih dari satu jam (Firman \& Rahman, 2020). Oleh karena itu selayaknya pihak sekolah lebih bijak dalam memberikan kebijakan berupa cara pembelajaran yang sesuai.

Persoalan yang terjadi di Papua tersebar berdasarkan letak geografis daerah. Salah satu keberadaan dapat dicontohkan pada daerah di wilayah hasil pemekaran. Salah satu contoh berdasarkan data di Kabupaten Asmat masih ditemukannya peserta didik pada level SMP dan SMA yang masih belum lancar menulis dan membaca. Hal ini jika dilihat dari latar belakang data berdasarkan PP No. 74 Tahun 2008 tentang guru, rasio minimal jumlah peserta didik terhadap guru khususnya Sekolah Dasar adalah 20:1, hal ini masih belum bisa dipenuhi karena rasio yang lebih besar dari 20 siswa (BPS, 2017).

Pendidikan dalam menunjang peningkatan Sumber Daya Manusia (SDM) didapatkan melalui kegiatan belajar yang terstruktur dan terukur. Adanya Sekolah Dasar di setiap kampung merupakan salah satu solusi dalam menunjang pendidikan. Karena itu, lembaga pendidikan diharapkan bukan hanya menghasilkan output saja, akan tetapi juga harus menghasilkan outcomes (Setiawan, 2020). Pada implementasi pendidikan yang secara bertahap diimplementasikan oleh tenaga pengajar. Guru merupakan media dalam menunjang berhasilnya proses belajar. Guru pada Sekolah tingkat Dasar harusnya mempunyai keahlian dalam melakukan refleksi serta menganalisis kegiatan selama mengajar. Karakteristik yang harus dimiliki guru yang selanjutnya juga harus bisa melakukan refleksi dari hasil refleksi yang telah dilakukan (Anhusadar, 2020).

Keberadaan dari proses belajar mengajar harus ditunjang oleh media belajar yang sangat mendukung. Selain media yang menunjang, penyesuaian dari karakteristik siswa. Keberhasilan suatu model maupun suatu media pembelajaran tergantung dari karakteristik peserta didik (Dewi, 2020). Dalam melakukan proses belajar mengajar, peran guru harus menentukan dari keberhasilan belajar. Keberadaan guru selain sebagai fasilitator juga sebagai penjelasan materi yang sesuai. Guru yang dulunya bertindak sebagai fasilitator dalam pembelajaran tatap muka, khusus pada saat Pandemi Covid-19, diharapkan guru lebih jeli dalam memberikan penjelasan materi bukan hanya pada inti materi tetapi juga dikaitkan dengan keberadaan kegunaan dari keilmuan yang sedang dipelajari. Untuk itu peran guru sangat menetukan materi yang harus di butuhkan siswa baik secara langsung maupun melalui peraga yang sesuai. Penyusunan materi dan penggunaan alat peraga dan media melalui pembelajaran online harus disesuaikan dengan tingkat perkembangan intelektual siswa sebagai peserta didik (Wiryanto, 2020). 


\section{Bekal Hidup Mandiri}

Keberadaan alam Papua mempunyai karakteristik sedikit berbeda dengan daerah lain. Hal ini dikarenakan posisi wilayah Provinsi di ujung timur Indonesia ini berada pada daerah dataran pegunungan, pesisir pantai, dan juga daerah yang berbatasan dengan negara lain. Masyarakat yang tinggal dan mendiami pulau Papua juga mempunyai karakteristik yang menyesuaikan dengan keberadaan alam disekitarnya. Misalnya saja keberadaan kampung yang berada di daerah pesisir pantai lebih dominan masyarakat bermata pencaharian sebagai nelayan, serta keberadaan yang dekat dengan hutan lebih mengandalkan kegiatan berburu dan meramu untuk mempertahankan hidup.

Keberadaan Orang Asli Papua atau yang lebih dikenal dengan orang lokal sangat identik dengan cara dan kebiasaan menghargai alam sebagai sumber dan juga sebagai tempat untuk melanjutkan kehidupan beserta keturunannya. Banyaknya budaya yang ada di mayarakat lokal lebih dominan menggambarkan budaya antara alam dan manusia (Sumarsono \& Wasa, 2018). Masyarakat yang hidup berdampingan dengan alam sangat memelihara keseimbangan ekosistem yang ada di alam. Salah satu bentuk harmoniasasi dengan alam telah dilakukan dengan selalu menjaga dan menggunakan ketersediaan alam dengan tidak berlebihan. Selain manusia harus hidup, manusia juga harus mengupayakan hasil alam untuk kebutuhan manusia pada anak cucu berikutnya.

Keberadaan dari kegiatan KKN/PPM pada program ini dilaksanakan di perkampungan lokal Papua tepatnya pada masyarakat yang tinggal di daerah pesisir pantai. Kebanyakan dari dominasi warga masyarakat yang bermata pencaharian sebagai nelayan. Jika dilihat dari keberadaan dari lahan disekitar tempat tinggal, terlihat sangat luas dan hanya dimanfaatkan untuk kegiatan pertanian setengahnya saja. Potensi yang dapat dioptimalkan melalui kegiatan pertanian sebenarnya sangat banyak. Hal yang merekomendasikan dari hal pertanian pada daerah lokasi KKN ini. Diantaranya dari lahan tanah yang sangat cocok untuk tanaman, tanah perpaduan dari tanah liat dan tanah berpasir sangat cocok untuk tanaman yang masa tanamnya cepat, misalnya cabe, sayuran, dan padi. Kualitas air yang berasal dari resapan air pantai dan berupa air tawar sangat mendukung dalam pengairan tanaman.

Kegiatan KKN yang dilaksanakan mendukung dalam program pengabdian ini dilaksanakan langsung kepada masyarakat guna memberikan peahaman tentang hidup mandiri dari bidang pertanian. Walaupun banyak masyarakat yang sudah memahami pertanian akan tetapi keilmuan dalam pola tanam, merawat, dan pemupukan serta cara membuat pestisida baik secara alami maupun secara non alami masih sangat kurang. Banyaknya potensi desa yang belum dimanfaatkan potensinya, oleh karena itu Perguruan Tinggi mempunyai peran dalam memaksimalkan potensi untuk mempercepat program pembangunan Nasional (DIKTI, 2019). Melalui kegiatan pengabdian ini dapat langsung diterapkan kepada Mitra.

Pelatihan, penerapan, dan pendampingan yang dilakukan secara terstruktur dapat memberpaiki pengetahuan masyarakat dalam bercocok tanam, memberikan pengalaman baru melalui keilmuan dalam bercocok tanam, serta memberikan pilihan dalam menanam dan memaksimalkan lahan pertanian Mitra. Jika masyarakat dapat maksimal dalam memberikan pengetahuan secara implementasi terapan ilmu, maka dapat dipastikan kemandirian dari masyarakat tersebut meningkat.

Efek yang ditimbulkan dari penerapan ilmu pertanian ini dapat dilihat dari pengembangan sistem usaha tani secara terpadu, efektif digunakan sebagai usaha merubah kebiasaan meramu menjadi petani tetap, hasilnya dapat diketahui bahwa pendapatan petani itu sendiri akan meningkat (Palobo, Ayakeding, \& Baliadi, 2017). Berdasar dari informasi serta memberikan bagian solusi yang telah diberikan pada contoh diatas dapat disimpulkan bahwa masyarakat masih membutuhkan ilmu terapan untuk langsung diterapkan pada Mitra secara maksimal. Keilmuan yang dapat di dapatkan dalam menempuh kehidupan dapat berupa bekal hidup mandiri dalam bidang pendidikan dan pemberantasan buta aksara melalui bidang pendidikan.

Tujuan dari Program pengabdian pada masyarakat melalui KKN-PPM ini adalah 
implementasi dari ilmu yang sudah di buktikan dalam bentuk penelitian dan selanjutnya dimplementasikan oleh mahasiswa ke masyarakat. Selain itu dari hasil implementasi juga peningkatan secara kuantitas dan kualitas masyarakat khususunya dalam dua program bidang yaitu bidang pendidikan dan bidang pertanian. Sedangkan manfaat dari kegiatan KKN/PPM ini secara spesifik adalah sarana mahasiswa untuk hidup berdampingan dengan masyarakat dalam mengimplementasikan ilmu. Manfaat selanjutnya adalah terciptanya harmonisasi antara dunia akademik kampus dengan Mitra masyarakat.

\section{METODE}

Program KKN-PPM yang dilaksanakan pada masyarakat Kampung Onggaya Distrik Naukenjerai terdiri dari dua kegiatan yaitu pemberantasan buta aksara yang dilaksanakan pada bidang pendidikan dan bekal hidup mandiri pada bidang pertanian. Jumlah mahasiswa yang dilibatkan dalam kegiatan ini sebanyak sepuluh mahasiswa. Materi yang diberikan melalui tiga tahapan yang dibagi menjadi empat minggu. Pada minggu pertama dan kedua masingmasing bidang melakukan kegiatan pelatihan dan penerapan, pada minggu ke tiga melakukan pendampingan dan pada minggu keempat melakukan evaluasi kerja lapangan. Ketiga metode yang sudah di sepakati dengan mitra, dilaksanakan secara bergantian yaitu pada siang dan sore hari. Adapun warga Mitra yang mengikuti lebih dominan diikuti oleh pemudapemudi kampung serta anak usia sekolah yang siap menjadi pioner keberlanjutan program setelah KKN-PPM. Adapun jumlah masyarakat terlibat sangat tentatif hal ini dikarenakan kesibukan masyarakat yang mengutamakan pemenuhan kebutuhan sehari-hari. Pada bidang pendidikan juga melibatkan guru dan juga siswa yang masih usia sekolah dasar dengan jumlah pasti sebanyak tujuh orang guru dan empat puluh tiga anak usia sekolah. Evaluasi selalu dilakukan setiap malam hari, guna mengetahui keterbatasan, kekurangan, dan kelebihan program yang telah dilaksanakan serta perencanaan untuk hari berikutnya. Adapun secara jelasnya, metode kegiatan KKN/PPM ini sebagai berikut:

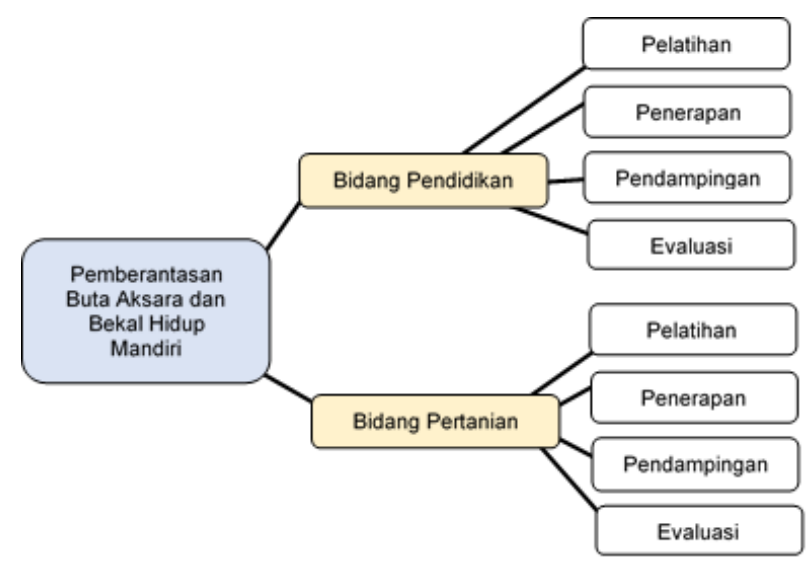

Gambar 1. Diagram Alir Metode Kegiatan Pengabdian KKN-PPM

\section{HASIL DAN PEMBAHASAN}

Kegiatan pengabdian kepada Masyarakat yang dilakukan oleh Mahasiswa dalam bentuk Kuliah Kerja Nyata (KKN) telah dilaksanakan sesuai dengan aturan dan pedoman pelaksanaan KKN. Kegiatan ini melibatkan sepuluh mahasiswa yang terdiri dari fakultas Pendidikan sebanyak enam orang dan mahasiwa dari fakultas pertanian sebanyak empat orang. Pelaksanaan dari KKN-PPM ini dilaksanakan selama satu bulan dari bulan Agustus hingga bulan September tahun 2020. Adapun pelaksanaannya di Kampung Onggaya Distrik Naukenjerai Kabupaten Merauke, Papua. Kegiatan KKN terlaksana dengan diawali dengan pembekalan, koordinasi dan pelepasan pada lokasi KKN, pelaksanaan dan diakhiri dengan penjemputan dari lokasi KKN.

\section{A. Bidang Pendidikan}

Fokus khusus dari bidang pendidikan adalah pengentasan buta aksara bagi warga masyarakat Kampung Onggaya Distrik Naukenjerai terkhusus pada anak usia sekolah. Pada saat dilaksanakan KKN ini masih diterapkan protokol kesehatan pada masa pandemi COVID-19. Dampak dari diliburkannya sekolah dan di hentikannya pembelajaran tatap muka membuat anak usia sekolah banyak yang tidak mendapatkan pendampingan belajar. Berdasarkan pendataan kepada warga masyarakat usia sekolah masih ditemukan anak usia sekolah yag sudah sekolah dasar pada tingkat atas yang masih kesulitan dalam proses membaca dan mengeja. Secara garis besar kegiatan ini dilaksanakan sebagai berikut: 


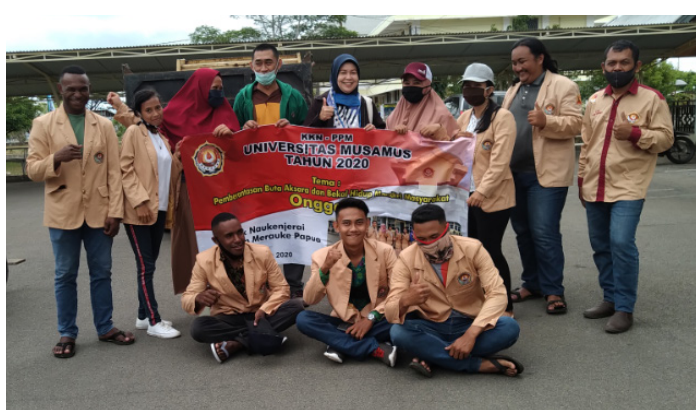

Gambar 2. Pemberangkatan KKN

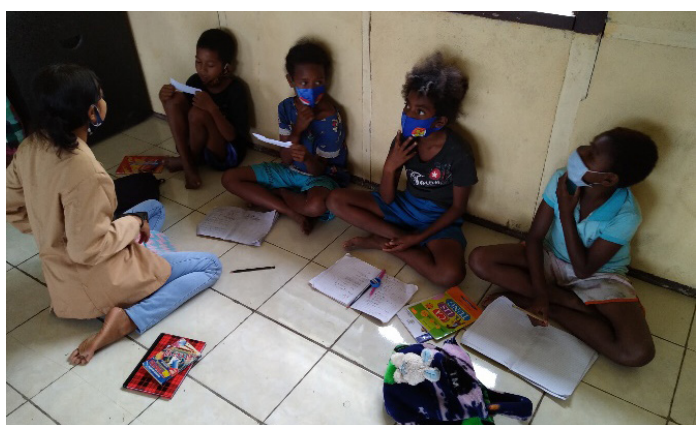

Gambar 3. Penerapan Mengajar secara Klasikal

\section{Pelatihan dan Penerapan}

Anggota wajib belajar dilakukan dari rumah-kerumah, rata-rata yang ikut bergabung dalam kegiatan belajar mengajar adalah anakanak. Setelah adanya sosialisasi yang intern dengan warga maka, disepakati bahwa untuk kegiatan belajar dilakukan pada pagi dan siang hari khusus untuk anak-anak serta pada saat waktu luang. Pada kegiatan pelatihan fokus adalah para anak usia sekolah dalam mengenal huruf, mengenal angka, dan menghafalkannya. Dalam waktu beberapa hari para pemuda sudah bisa, hal ini dikarenakan karena para anak-anak sudah pernah sekolah jadi hanya membutuhkan waktu untuk mengingatnya kembali saja. Media yang sudah disediakan oleh mahasiswa untuk mengajar adalah papan tulis, alat tulis, buku, rangkaian gambar jenis huruf dan angka, serta operasi pengurangan dan penjumlahan.

\section{Pendampingan}

Hal yang sangat penting dalam memberikan materi calistung adalah peran pendampingan. Hal ini karena kesibukan mayarakat yang biasa hanya ramai dan semangat diawal saja, hal ini dikarenakan kesibukan warga masyarakat untuk mencari pemenuhan kebutuhan di hutan. Pendampingan hanya dilakukan pengecekan kembali kepada warga belajar dari kegiatan membaca dan berhitung serta menerapkannya dalam kehidupan setiap harinya.

\section{Evaluasi}

Kegiatan dari bidang pendidikan ini pada tahap akhir dilakukan evaluasi, adapun penjabaran dari kegiatan evaluasi untuk mengukur keberhasilan program yang sudah selesai dilaksanakan. Pada bahasan pemberantasan buta aksara, khusus bagi pemula didapatkan peningkatan yang dapat dilihat pada Gambar 4.

Berdasarkan hasil pelaksanaan program pengentasan buta aksara yang dilakukan pada warga lokal kampung Onggaya sangat menggembirakan. Hal ini lebih dikarenakan semangat warga masyarakat yang selalu mendukung. Pada saat wabah pandemi, anakanak sangat semangat karena sekolah sudah lama tidak melaksanakan pembelajaran tatap muka.

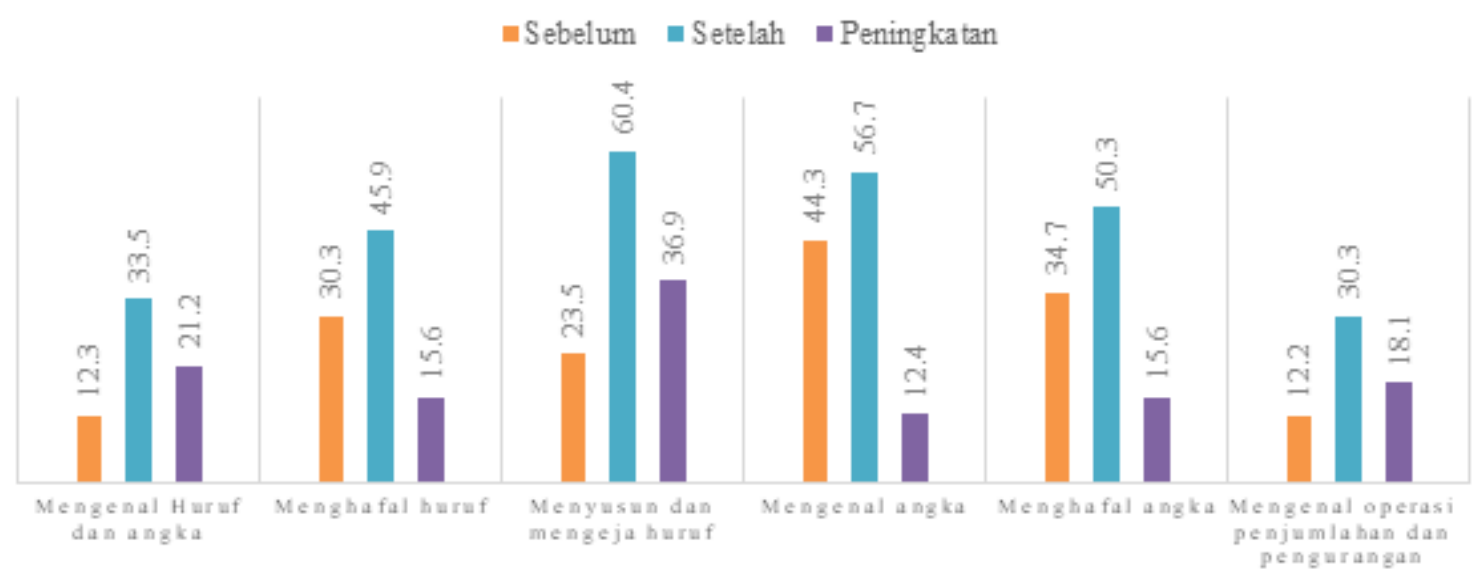

Gambar 4. Hasil Evaluasi Kegiatan Program Bidang Pendidikan 


\section{B. BIDANG PERTANIAN}

Berbeda dari program pendidikan, pada bidang pertanian lebih ditekankan pada nuansa praktik lapangan. Pada bidang pertanian, sesuai dengan rancangan kegiatan pelaksanaan dilakukan pada warga setempat yang lebih menekankan pada pertanian. Setelah melakukan adaptasi lingkungan, maka selanjutnya melakukan pemetaan tentang kondisi lahan, kemungkinan tanaman yang cocok dan peralatan pertanian. Adapaun secara legkap kegiatan yang telah dilaksanakan sebagai berikut:

\section{Pelatihan dan Penerapan}

Tahap pelatihan adalah tahap paling awal dalam kegiatan ini adalah hal yang sangat penting. Pelatihan dilakukan beberapa kali di rumah warga karena beralasan sangat sulit untuk mengumpulkan warga masyarakat. Kesibukannya dalam mencari bahan makanan di hutan, mengakibatkan fokus pelatihan dilakukan dari rumah kerumah. Setelah pelatihan, kegiatan yang dilakukan adalah penerapan dari materi teori yang telah disampaikan. Penerapan dilakukan langsung dalam membuat lahan tanaman sayur-sayuran, merawat, dan juga memupuknya. Pada hal pupuk dilakukan penjelasaan dengan membuat pupuk kompos dan pupuk alami dari hasil sisa limbah rumah tangga. Adapun gambar dari kegiatan pelatihan dan penerapan sebagai berikut:

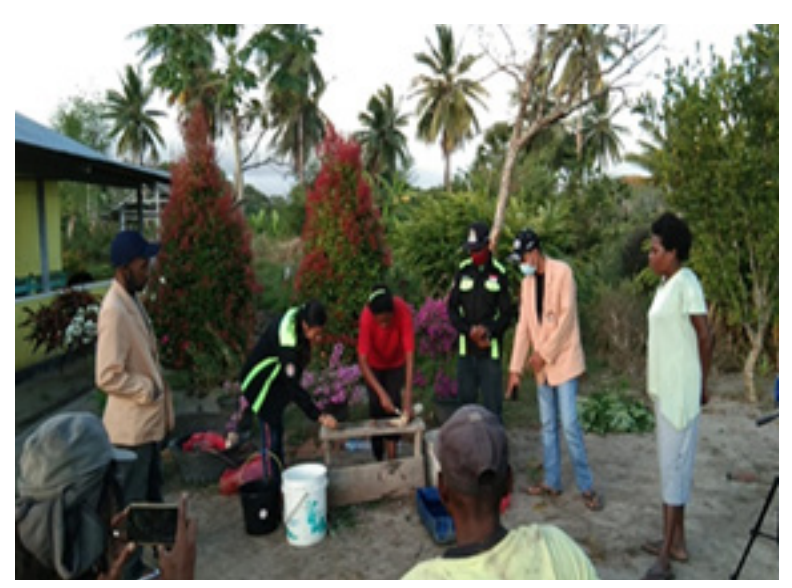

Gambar 5. Pelatihan

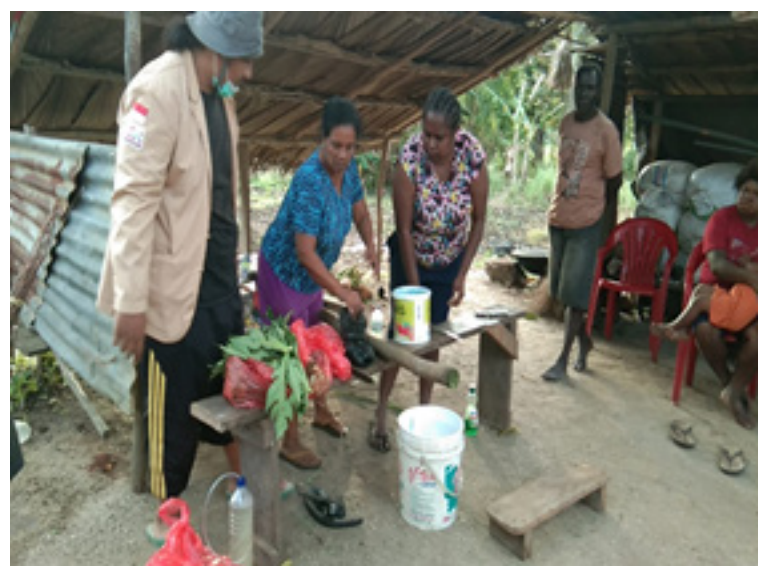

Gambar 6. Pelatihan Pembuatan pestisida alami

Kegiatan

pengawasan dan mendampingi warga masyarakat lokal Papua, yang dibiarkan untuk kerja tanam menanam tumbuhan yang berupa tumbuhan sayuran, buah-buahan dan yang berada di pesisir sungai diajari cara membuat bendungan dan irigasi. Pemahaman warga yang dibina meningkat dengan selang bebrapa lama hasil dari pertanian yang sudah dihasilkan telah membuahkan hasil. Misalnya tanaman sayur mayur yang sudah bisa dirawat. Warga sangat antusias dalam melakukan perawatan yaitu pengairan dan pemupukan tanaman yang dilakukan secara bergantian.

\section{Evaluasi}

KKN-PPM bidang pertanian ini, diawal dari pelaksanaan program sudah dilakukan identifikasi pengetahuan dan pemahaman tentang cara bercocok tanam. Melalui perbedaan dari hasil identifikasi awal dan identifikasi akhir program dapat dijelaskaan bahwa, secara pengetahuan warga sangat mampu dalam mengambil fokus inti dari penjelasan yang sudah disampaikan oleh mahasiswa KKN. Pemahaman warga tentang bercocok tanam meningkat dengan dilakukanya penyuluhan secara bertahap terhadap lahan yang tidak digunakan disekitar rumah untuk ditanami berbagai macam tanaman dan sayuran. Penggunaan alat pertanian yang sudah ada belum dimaksimalkan karena dalam anggapan warga bahwa alat pertanian maju harus menggunakan mesin pertanian. 


\section{KESIMPULAN}

Melalui program KKN ini sangat diapresiasi warga dalam membuat dan menambah pengetahuan nyata sesuai dengan kebutuhan hidup. Dua bidang yang telah dilaksanakan sangat bermanfaat sesuai dengan kebutuhan. Upaya pemberantasan buta aksara supaya warga masyarakat di kampung Onggaya Distrik Naukenjerai. Keberadaan mahasiswa sebagai agen perubahan cendekia sangat diperlukan, hal ini dapat dilihat dari kegiatan pemberdayaan yang pada setiap programnya sudah mencapai keberhasilan. Program KKN-PPM yang telah dilaksanakan ini sudah mengganti pola dari program KKN sebelumnya yaitu dari fokus pembangunan fisik menjadi fokus pembelajaran dan pemberdayaan masyarakat. Khususnya dari program pendidikan, walaupun telah berhasil membuat komunitas pemuda pemudi dalam memberikan bekal ilmu melalui baca tulis hitung, dan juga anak-anak usia sekolah sudah mampu mengenal baca tulis dan angka, ternyata program ini masih menyisakan kelemahan. Kesulitan warga masyarakat utamanya anakanak masih kesulitan membedakan bunyi huruf mati, contohnya huruf "Y" dan huruf "J". Dalam mengenal angka pembelajaran hingga operasi penjumlahan dan pengurangan sulit dimengerti karena belum menguasai dan belum hafal nama bilangan. Selanjutnya pada bidang pertanian yang sudah dilaksanakan sangat memberi kesan positif tentang ilmu tanam menanam. Masyarakat sudah dapat mengerti prinsip dasar tanaman supaya dapat tumbuh, penyiraman, pemupukan, dan panen. Dari lahan kosong sekitar pekarangan rumah sudah banyak yang sadar dalam menanam dan menggunakan pekarangan rumah untuk menanam sayuran. Selain itu program pertanian juga mengajarkan dalam pembuatan pupuk kompos yang didapatkan dari alam. Hasil nyata dari bidang pertanian adalah kini masyarakat sudah bisa membuat ramuan pestisida alami dan langsung dapat digunakan dalam memelihara tanaman dari serangan hama. Lahan yang tadinya tidak di gunakan sekarang sudah di maksimalkan dengan penanaman buah-buahan dan tanaman produktif lainnya.

Masukan dari warga untuk kegiatan serupa berikutnya kalau bisa ada yang fokus untuk memperdayakan peternakan dan perikanan, hal ini sangat beralasan karena selain berada di dataran rendah, Kampung Onggaya berada di pesisir pantai yang sebagian banyak masyarakat menjadi nelayan. Selain itu kampung Onggaya mempunyai banyak anak sungai yang dapat digunakan untuk mata pencaharian sebagai pencari ikan. Adapun kesulitan warga yang mengikuti program pertanian sering mengeluhkan tentang asupan bibit tamanam maupun bibit sayuran. Karena jauh dari kota maka diharapkan peran pemerinah daerah untuk dapat memberikan pasokan bibit tanaman yang diperlukan warga.

Hal yang belum tersentuh dari program ini adalah bidang kesehatan. Diharapkan dari program KKN PPM selanjutnya dapat melanjutkan program yang belum selesai dari program ini serta dapat mengembang pada pemberdayaan pada permasalahan bidang kesehatan. Khusus nya pada waktu pandemi Covid-19, kegiatan pengabdian pada KKN PPM masih sebatas mengarahkan masyarakat dalam mematuhi protokol kesehatan yang maksimal.

\section{PERSANTUNAN}

Program pengabdian kepada Masyarakat telah selesai dilaksanakan, kami tim pengabdian KKN-PPM Universitas Musamus, mengucapkan terima kasih kepada DRPM dari KEMENRISTEK/ BRIN melalui SIMLIBTABMAS tahun pelaksanaan 2020. Kegiatan pengabdian ini telah didanai melalui kontrak No. 117:1/UN52.8/PM/2020, Ucapan terima kasih juga diucapkan kepada warga kampung Onggaya distrik Naukenjerai Kabupaten Merauke, Papua yang seluruhnya mendukung program KKN/PPM ini. Ucapan terima kasih juga diucapakan kepada Lembaga Penelitian dan Pengabdian Kepada Masyarakat (LP2M) Universitas Musamus yang telah memfasilitasi dengan memberikan izin dan ilmu sehingga program pengabdian KKN-PPM ini dapat dilaksanakan dengan maksimal. Terucap doa semoga kerjasama dalam pengabdian masyarakat ini akan terus berlangsung dan penerapan ilmu yang ada di dunia kampus tidak hanya sebagai sarana akademik semata akan tetapi dapat di aplikasikan dalam dunia nyata khususunya program yang berguna bagi masyarakat lokal di tanah Papua. 


\section{REFERENSI}

Anhusadar, L. O. (2020). Persepsi Mahasiswa PIAUD terhadap Kuliah Online di Masa Pandemi Covid-19. Kindergarten: Journal of Islamic Early Childhood Education, 48.

Asmat, B. K. (2016). Indeks Pembangunan Manusia (IPM) Tahun 2015 di Kabupaten Asmat. Agats: BPS Kabupaten Asmat (BRS-02/BPS-9415/Th. I 26 Juni 2016.

Asmat, B. P. (2018). Indikator IPM. Asmat: BPS Asmat.

BPS Kabupaten Asmat, B. (2016). Kabupaten Asmat dalam Angka. Asmat: BPS Kabupaten Asmat.

BPS, K. (2017). Statistik Daerah Kabupaten Asmat. Asmat: BPS Asmat.

Dewi, W. A. (2020). Dampak Covid 19 Terhadap Implementasi Pembelajaran Daring di Sekolah Dasar. Educatif: Jurnal Ilmu Pendidikan Vol. 2 No. 1, 56.

DIKTI. (2019). Kiprah Direktorat Jenderal Penguatan Riset dan Pengembangan 2015-2019. Jakarta: Direktorat Jenderal Penguatan Riset dan Pengembangan DIKTI.

Firman, \& Rahman, S. A. (2020). Pembelajaran Online ditengah Pandemi Covid-19. Indonesian Journal of Education Science (IJES) Vol. 2 No. 2, 85.

Kartono, A. (2013, Juli). https://regional.kompas.com/read/2013/07/04/1813406/Beginilah. Potret.Pendidikan.di.Kabupaten.Asmat. Diambil kembali dari https://regional.kompas.com/ $\mathrm{read} / 2013 / 07 / 04 / 1813406 /$ Beginilah.Potret.Pendidikan.di.Kabupaten.Asmat: https://regional. kompas.com/read/2013/07/04/1813406/Beginilah.Potret.Pendidikan.di.Kabupaten.Asmat

Malawat, I., \& Mofu, H. (2018). Tradisi suku Asmat dalam Roman Namaku Teweraut Karya Ani Sekarningsih. Retorika, Jurnal Bahasa dan Sastra dan Pengajarannya, 155.

Palobo, F., Ayakeding, E., \& Baliadi, Y. (2017). Prospek Usahatani Kacang Hijau dalam Pemanfaatan Lahan di antara Pertanaman Kelapa pada Wilayah Perbatasan Merauke Papua . Seminar Hasil Penelitian Tanaman Aneka kacang dan Umbi, (hal. 503). Jayapura.

Perkebunan, D. J. (2016). Statistik Perkebunan Indonesia 2015-2017. Jakarta: Sekretariat Derektorat Jenderal Perkebunan Kementerian Pertanian.

Setiawan, A. R. (2020). Lembar Kegiatan Literasi Saintifik untuk Pembelajaran Jarak Jauh Topik Penyakit Coronavirus 2019 (COVID-19). Jurnal Edukatif:Jurnal Ilmu Pendidikan, 2(1), 30.

Sumarsono, A., \& Mubarokah, F. (2019). The Developement of Learning Method "Imagination Box": An Effective and Efficient Method to Evaluate Student's Understanding. Jurnal Pendidikan Progresif Vol. 9 No. 1, 59.

Sumarsono, A., \& Sianturi, M. (2018). Implementation Interactive Media and Characterized Meme Media: A Comparation Study. Journal of Education and Vocational Research (ISSN 2221-2590) Vol. 9, No. 1.

Sumarsono, A., \& Sianturi, M. (2019). Peluang Media Interaktif dalam Menunjang Efektivitas Pembelajaran Tematik di Sekolah Dasar. Jurnal Edutama Pendidikan, 12.

Sumarsono, A., \& Wasa, C. (2018). Traditional Sasi wisdom in Papua-based nature conservation. IOP Conference Series: Earth and Environmental Science (hal. 5). Makassar: IOP Publishing.

Sumarsono, Adi ; Santo, Zem ; Hidayat, Afif Khoirul. (2017). Pengembangan Model Pembelajaran Atletik Melalui Permainan Berbasis Alam pada Sekolah Dasar Daerah Perbatasan RI-PNG. Seminar Nasional Kependidikan Inovasi pendidikan dan pembelajaran dalam rangka percepatan pembangunan didaerah pinggiran (hal. 28). Merauke: Fakultas Keguruan dan Ilmu Pendidikan, Universitas Musamus Merauke.

Wiryanto. (2020). Proses Pembelajaran Matematika di Sekolah Dasar di Tengah Pandemi Covid-19. Jurnal Review Pendidikan Dasar: Jurnal Kajian Pendidikan dan Hasil Penelitian Vol. 6 No. 2, 6. 